\title{
Open
}

\section{Gene patents still alive and kicking: their impact on provision of genetic testing for long QT syndrome in the Canadian public health-care system}

\author{
Sarah E. Ali-Khan, $\mathrm{PhD}^{1}$ and E. Richard Gold, SJD ${ }^{1,2}$
}

\begin{abstract}
Purpose: Although the Supreme Court of the United States limited their availability in Association for Molecular Pathology v. Myriad Genetics, gene patents remain important around the world. We examine the situation in Canada, where gene patents continue to exist, in light of recent litigation relating to familial long QT syndrome (LQTS).
\end{abstract}

Methods: We conducted in-depth semistructured interviews with 25 stakeholders across five Canadian provinces and supplemented this with a case analysis of the litigation.

Results: The majority of LQTS testing was carried out outside Canada. Rising costs prompted several provinces to attempt to repatriate testing. However, LQTS gene patents stymied efforts, particularly in provinces where testing was more centralized, increasing costs and lowering innovation. It was in this context that a hospital launched a test case against the LQTS patents, resulting in a novel agreement to free Canadian hospitals from the effects of patents.

Conclusion: Our analysis reveals a rapidly evolving genetic test provision landscape under pressure from gene patents, strained budgets and poor collaboration. The litigation resulted in a blueprint for free public use of gene patents throughout Canada's health-care system, but it will only have value if governments are proactive in its use.

Genet Med advance online publication 11 May 2017

Key Words: access; equity; gene patents; intellectual property; long QT syndrome

\section{INTRODUCTION}

While the highest courts in the United States and Australia have limited the availability of patents on natural gene sequences, ${ }^{1-3}$ the number of gene-related patents continues to rise, ${ }^{4}$ and they remain important elsewhere. Research suggests that in Canada, these patents have seriously impeded equitable and cost-effective genetic testing. ${ }^{5}$ A recent legal settlement between a hospital and a patentholder may hold the key to reversing this situation. To explore both the underlying problem and its potential solution, this qualitative study ${ }^{6}$ draws on interviews conducted between September 2013 and October 2015 with stakeholders closely involved with genetic test provision (see Table 1), and discusses the legal settlement. This article represents the first detailed analysis of how gene patents affect genetic services in Canada. $^{7}$

Our exploration surrounds a widely reported gene patent litigation launched by the Children's Hospital of Eastern Ontario (CHEO) against the patentholder of five genes over a genetic test related to Long QT syndrome (LQTS) ${ }^{8-10}$ (see Supplementary Boxes S1 and S2 online). The case arose in Canada's public health-care system. Here, we document stakeholder concerns that gene patents reduced access, innovation and affordability. With the litigation recently settled, we investigate the potential of its Public Health Access
Agreement (the CHEO agreement) to provide a pathway for Canadian public providers to freely (without cost and without permission) incorporate patented genes into their genetic tests.

\section{MATERIALS AND METHODS}

To assess the potential impact of the CHEO agreement on the Canadian clinical genetics landscape, it is first necessary to understand the problems that it seeks to address. Thus, before analyzing the agreement, we introduce a qualitative study based on interviews with relevant stakeholders during the pendency of the litigation.

\section{Study sample}

Because the relevant community is relatively limited and challenging to access, we used purposive and snowball sampling methods to identify study participants, until we reached a saturation point ${ }^{11}$ (for full method details reported according to the Consolidated Criteria for Reporting Qualitative Research (COREQ) guidelines; ${ }^{12}$ see Supplementary Methods). Initially, we identified key informants from publicly-available sources, including the Gene Tests website (https://www.genetests.org/laboratories/?region $=$ can), which lists 26 Canadian genetic testing laboratories. We identified 12 public laboratories as potentially relevant to our study, and

${ }^{1}$ Centre for Intellectual Property Policy, Faculty of Law, McGill University, Montreal, Canada; ${ }^{2}$ Department of Human Genetics, McGill University, Montreal, Canada. Correspondence: E. Richard Gold (Richard.gold2@mcgill.ca) 
Table 1 Breakdown of study interviewees by professional role

Professional role Number interviewed

\begin{tabular}{ll}
\hline $\begin{array}{l}\text { Cardiologists/electrophysiologists, including } \\
\text { clinical scientists }\end{array}$ & 7 \\
$\begin{array}{l}\text { Molecular diagnostics public laboratory directors } \\
\text { ("directors") }\end{array}$ & 8 \\
Medical geneticists & 4 \\
Genetic counselors & 3 \\
$\begin{array}{l}\text { Genomic researchers/technology developers } \\
\text { ("developers") }\end{array}$ & 3 \\
Commercial long QT syndrome test providers \\
(based in the United States) \\
Total
\end{tabular}

one private laboratory offering LQTS testing. Excluding CHEO, we invited directors from these laboratories to our study. We note that Dr. Gold advised the CHEO litigation team on the policy implications of the case. To avoid any perception of a conflict of interest, he did not participate in the study interview process (including informant identification and contact), nor has he had access to the identifiable data. Further, to avoid bias, we did not invite any CHEO employees, lawyers or consultants to be interviewed in this research.

We invited 45 key informants to participate, 26 of whom were interviewed. Interviewees spanned Ontario (9), Alberta (4), British Columbia (6), Quebec (4) and the Maritimes (2) representing 14 public institutions (see Table 1). Here, we focus on information regarding these five provinces. One or more laboratory directors from eight public laboratories agreed to participate. Additionally, we interviewed one United States-based commercial provider of LQTS testing.

\section{Data analysis and reporting}

Data were analyzed using thematic content analysis techniques ${ }^{6}$ and managed using NVivo software. ${ }^{13}$ In this report, we often indicate the number of interviewees expressing the opinions described (clinicians, including genetic counselors (14); laboratory directors ("directors") (8); researchers/technology developers ("developers") (3); and Canadian interviewees (24)), implying two limitations. First, our study sample is nonrandom, although we endeavored to make it broadly representative of relevant Canadian stakeholders. Second, in semistructured interviews, participants respond according to their individual knowledge and expertise. Thus, content across interviews may not always be directly comparable. With these caveats noted, the inclusion of proportions may enhance this study's informativeness. ${ }^{14}$

\section{RESULTS}

Our study of stakeholders identified five major themes and several subthemes (see Supplementary Methods). Here, we describe the three major themes and subthemes that are most relevant to our study goal.

\section{LQTS test provision in Canada before the settlement Outsourcing of LQTS testing}

Our analysis indicates that before the settlement the vast majority of LQTS testing was not carried out in Canada. All but one institution shipped patient samples out of the country, mostly to laboratories run by LQTS gene patent licensees in the United States, namely Transgenomic, ${ }^{15}$ who were a party in the CHEO test case after it acquired the patents, and GeneDx ${ }^{16,17}$ (see Supplementary Box 1). Clinicians and directors expressed unanimous satisfaction with these services. However, all but one (a clinician) stated that United States-based testing is costly, citing between US $\$ 3,000$ and US $\$ 4,000$ per test panel (the exact costs differed by testing center due to bulk order negotiations).

\section{Increasingly strained genetics budgets}

Almost all directors (6 of 8) emphasized that laboratory budgets are stretched and that the demand for molecular testing is growing. Consequently, most provincial authorities have chosen to centrally administer test outsourcing. However, the approval process for out-of-country applications is generally resource-intensive. While directors and clinicians affirmed that LQTS applications are almost always approved because of the diagnostic's proven clinical utility, directors noted that this necessitates that other important requests be refused.

\section{Siloed budgets and health-care systems}

Many interviewees (directors (5 of 8), clinicians (6 of 14) and one developer) complained that the valuation of genetic services in their respective provinces is poor and that mechanisms to evaluate the clinical utility and overall health-care system impact of molecular testing are undeveloped. ${ }^{18}$ For example, clinical efficiencies resulting from LQTS genetic testing, such as sparing asymptomatic family members who test negative from ongoing follow-up, are not channeled back to fund genetics programs. Several directors ( 2 of 8 ) and developers ( 1 of 3 ) further noted that provincial siloing of healthcare obviates collaboration and efficiencies of scale.

\section{Access to LQTS testing}

Clinicians and directors reported that patient access to LQTS testing before the settlement was generally very good. However, a few ( 1 of 14 clinicians and 1 of 3 technology developers) said that the application process may deter some clinicians in "borderline" or less definitive clinical cases. Others ( 1 of 14 clinicians and 1 of 8 directors) suggested that beyond tertiary-care centers, knowledge of test availability may be limited. One clinician said gaining approvals for those beyond child-bearing age or without children sometimes posed challenges. Another said colleagues from other provinces had requested their assistance in accessing testing. 
Consequently, in some circumstances patient access may be less than optimal (see Supplementary S3 and Supplementary Data). A few directors (2 of 8 ) predicted that, similar to other repatriated tests, LQTS test volumes would probably increase dramatically if local testing was available.

\section{Desire for local LQTS testing Clear benefit to local testing}

In line with the litigation commenced by CHEO, Canadian interviewees almost unanimously supported the notion of establishing local LQTS testing (23 of 24), describing clinical, scientific, ethical, and economic advantages. A central concern raised by outsourcing testing beyond Canada is a resulting disconnect between patients' genetic and clinical information. Local testing would allow closer integration, enabling more comprehensive test interpretation and optimized patient care. Retaining genetic data locally, rather than in foreign firms, would create local research opportunities. Finally, conducting tests in Canada would retain the economic benefits of millions of dollars of testing business, while building local genetics capacity. Many directors and clinicians emphasized the potential logistical ease and efficiency of local testing. One director voiced concerns about privacy risks when patients' genetic data are stored in foreign jurisdictions. Two clinicians noted that test turn-around times would be improved. However, almost all Canadian interviewees (22 of 24) underscored the cost-effectiveness of local testing. Several directors (3 of 8 ) and developers (2 of 3 ) estimated that tests could be done locally for one-half to onequarter of the prices charged by commercial providers in the United States. One clinician summarized this thought as follows:

“There's...something fundamentally wrong about having to ship Canadian samples out of country to do testing that Canada's actually very capable of doing."

Only one interviewee (a clinician) expressed concern about repatriation. They wondered whether Canadian public laboratories could achieve the comprehensive test interpretation delivered by commercial providers, because some of the latter draw on extensive private databases. However, all directors outlined potential solutions, including: licensing commercial databases; collaborating with current LQTS test providers; drawing on public, but disparate locus-specific LQTS databases; recovering patient data from test providers; building their own databases using local samples; and collaborating with local and regional cardiac genetics experts. Several directors (3 of 8 ) and clinicians (2 of 14) noted that federating genomic and anonymized phenotypic information across provincial borders, subject to patient consent and privacy protections, would be essential to build critical mass and optimize local capacity.

Our research identified only one Canadian institution, in Quebec, that carried out local LQTS testing before the settlement. It has run Sanger-based testing for the five major
LQTS genes since 2008. It recently replaced this test with a next-generation sequencing panel of 112 pan-cardiac genes, including for LQTS.

\section{The rising costs of outsourcing tests}

According to directors (7 of 8 ) the cost of out-of-country testing was becoming unmanageable. For example, in 2010 fewer than $15 \%$ of molecular tests ordered in Ontario were performed in province. ${ }^{19}$ The rest were outsourced, mainly to the United States, at a cost of US\$24 million in the 2013-14 fiscal year. ${ }^{20}$ Such figures prompted moves to repatriate high-volume, high-cost tests, whose referrals were increasing, $^{21}$ including LQTS. A key enabler for local implementation of multiplex tests is the increasing affordability of next-generation sequencing technology. Directors (7 of 8), clinicians (4 of 14) and developers (all 3) indicated that, until recently, using commercial providers was the practical choice for most Canadian stakeholders. However, our analysis indicates that public laboratories across all provinces in our study are now considering, or have already attempted, repatriation of LQTS testing. Access to funding has been a persistent barrier, but gene patents have also been a key stumbling block.

\section{Perverse incentives for local test implementation}

The significant costs of working up new tests, including validation, gaining laboratory accreditation, hiring staff and purchasing capital equipment, are the purview of the public institution wishing to implement the test. It must then pay for each test performed. In contrast, tests that are sent out of the country in Ontario, British Columbia and Quebec are paid for directly by the province. Consequently, one director noted that, in Ontario at least, there is a financial disincentive for institutions to set up tests requiring significant work-up, such as LQTS. In contrast, the Ontario repatriation initiative offers an attractive alternative. Under this model, a single institution or team of institutions is established as the provincial reference laboratory for a particular test, and the ministry pays for all tests performed. Test work-up costs, however, are still borne by the institution.

\section{Gene patents hinder repatriation}

Around 2009, both Ontario and British Columbia sought to repatriate LQTS testing. In Ontario, this involved inviting hospitals to bid for the provincial testing contract. ${ }^{21}$ In British Columbia, one institution had a test for the five major LQTS genes ready for implementation. However, in early 2010 both the Ontario Ministry of Health and Long-Term Care (MOHLTC) and the British Columbia institution received warning letters from PGx Health, which wrongly identified itself as the patentholder of one of the genes-(KCNQ1 (formally called KVLQT1)), which is now owned by $\mathrm{PGx}$ Health's successor firm, Transgenomic-advising them of the recently issued Canadian patent. Interviewees said that, subsequently, legal counsel for both provinces advised that LQTS repatriation be dropped. 


\section{Shifting sands regarding policy on diagnostics patents}

Provincial health authorities, institutions and public laboratories face a difficult choice. They can ignore gene patents and risk litigation for infringement, or approach patent holders and negotiate a license. However, such licenses can be costly. Unlike commercial firms, which undertake an analysis of the scope and validity of patents, hospitals do not have the budget to do so. Directors (7 of 8) noted that institutions and ministries are risk-adverse and have very limited funds to pay for the use of patented diagnostics. Almost all directors (7 of 8) and clinicians (all 14) explicitly stated that patient care ought to take priority over patents, but some noted that, in practice, this is not always the case. Likewise, informants were unanimous in questioning the patentability of naturally occurring genes. One said:

“To be able to say that I can't use my own brain to design

my very own test for testing a gene that is found in nature is really quite ridiculous."

Thus, perhaps unsurprisingly, several directors (5 of 8) and one clinician stated that public sector laboratories in Canada are currently infringing "all over the place," although not necessarily in relation to the LQTS patents.

Our research identified only one piece of official policy or guidance from institutions or ministries on the management of gene patents (http://paceomics.org/index.php/quebecministere-de-la-sante-et-des-services-sociaux-letter-to-quebecdiagnostics-labs/). This was issued by the Québec Ministère de la Santé et des Services Sociaux in 2008, after several public laboratories received letters from Warnex Inc. claiming exclusive rights to test for the V617f Jak2 mutation. The letter demanded that testing be performed in Warnex's laboratory at premium prices. The ministry, finding no evidence to support this claim-no patent had actually been issued-adopted the official position that public laboratories in Quebec continue Jak2 testing. One Quebec director stated that their institution took this missive as applicable to other genes.

Directors from other provinces reported various scenarios. A few (2 of 8 ) noted that their institutions hold several gene patents that yield significant revenues through licensing and royalty fees. They said that the resulting conflict of interest precluded an overarching institutional policy on gene patents. Several (4 of 8) said that Canadian laboratories generally take a "Don't ask, don't tell" approach, ${ }^{22}$ addressing intellectual property on tests in a case-by-case manner. However, almost all said that the lack of clarity, and of any open discussion between institutions or with provincial health authorities, leaves directors in an uncomfortable position. As a possible testament to this, three did not respond to study invitations and one was forbidden by their institution to participate in this study.

Our analysis further indicates that government and institutional decision-making processes relating to the LQTS gene patents vary across provinces. Directors in Ontario and British Columbia reported that their institutions and health authorities were very concerned about the legal risk gene patents posed. Others (2 of 8 ) said that, in the absence of more recent guidance, they simply assumed that their institution's approach had not changed since provincial authorities defied the demands of BRCA1 and 2 gene patent holder Myriad Genetics in the 2000s. ${ }^{23}$ In Quebec, one developer stated that the LQTS patents were deemed irrelevant to their institution's decision to implement testing because, as a public laboratory, they performed these tests at cost.

\section{Passing the "patent problem" to institutions}

Ontario's approach to gene patents has changed since 2010. In 2013, the MOHLTC launched another repatriation drive for LQTS. This time, it requested that institutions applying for the provincial contract describe how the institution itselfwould address gene patents impinging on the test. One director said:

"They basically decided that they would protect themselves, and not take a stance (on gene patents), and try to turn all of the patent issues back on the hospital. So in the application, it says that the Ministry has no involvement in the patent issues. If you're going to offer them, you have to deal with them yourself."

Ontario's overall approach to repatriation garnered the criticism of both Ontarian directors and three of its five clinicians. It was said to be nontransparent and overly competitive, disincentivizing collaboration between groups. Further, it obligated individual institutions to conduct the legally specialized task of identifying, interpreting and navigating intellectual property law-tasks directors stated they were not equipped or resourced to perform. ${ }^{24}$ With repatriation processes ongoing, it was said that this piece-meal and duplicative approach is particularly impractical.

\section{A lack of unified policy short-circuits repatriation}

The MOHLTC's 2013 approach to repatriation has prolonged the confusion over gene patents. Around December 2013, an Ontario team was awarded the provincial contract for LQTS testing. However, by October 2015, test development had still not commenced because of continuing uncertainty about the patents. Due to the high costs involved, both Ontario directors said they would not work up the test until the contract was confirmed. However, the contract crucially depended on the cost of test provision, which depended on whether licensing fees would be paid to the patent holders. In their application, the Ontario team provided their own estimate of licensing costs, as they hesitated to contact the patentholders until they were certain that such official acknowledgment of gene patents was the best approach. However, if the licensing fee ended up being higher than what the MOHLTC could afford to pay, the institution would not be able to implement the test. Uncertainties about the ownership and relevance of the many LQTS patents and claims in existence added to the complexity. By March 2016, this catch-22 was still not resolved. One director stated that 
the process had been incredibly resource-intensive. In the meantime, the province continued to outsource LQTS testing, paying premium prices. Thus, lack of leadership by provincial authorities stalled local testing, whereas an open, collaborative approach may have sped up repatriation. In the words of one director:

"If we had a provincial or even a national plan on how we were going to behave as a group, that would have given us an awful lot more backing and clarity on what we needed to do, but that's not what's happened and now every institution has its own plan and nobody tells anybody else."

\section{DISCUSSION}

Legal $^{25}$ and technological evolution, growing demand and increasing fiscal pressure is pushing a sea-change in genetic test provision in Canada $20,21,26,27$ and beyond. ${ }^{28}$ In this context, our analysis demonstrates how gene patents slowed institutional and provincial decision making, and blocked repatriation of LQTS testing in the years preceding the 2016 CHEO agreement, and sets the stage for analysis of the likely effects of that agreement. We found that the existence of patents drew on funds that could have been better spent elsewhere, and deprived local innovators, genetic service providers, researchers, clinicians and patients of the opportunity to benefit from equitable, cost-effective testing, access to data and associated research activities. While our study focused on just one genetic disorder, gene patents have posed ongoing uncertainties for imminent diagnostic technologies, ${ }^{29}$ and for continuing repatriation efforts. ${ }^{21}$

We found that the processes for establishing new tests vary by province, revealing differential effects of gene patents. The more centralized the decision-making process, the more problems that patents presented. In Ontario and British Columbia, institutions wishing to implement new tests must register or license them with provincial authorities. During these processes the LQTS patents raised the concern of ministries, hindering repatriation. However, in provinces where decisions about test implementation are made at the level of the laboratory director or the hospital, patents were less of a problem. Nevertheless, centralized processes are important because they can allow monitoring and potentially better assessment of health system impact, improved resource allocation, and cost savings. ${ }^{26}$

Against this backdrop, we evaluate the potential effects of the CHEO agreement. As a contractual agreement between parties to the litigation, it does not, per se, alter Canadian law or practice. Nevertheless, it offers the potential to serve as a precedent for future agreements-one that can be required though Canada's Patent Act-but only if governments and institutions develop the procedures and policies to do so. Thus, Canada can continue to accept the higher costs and lower access and innovation incumbent with the situation described in this article, or choose to alter that landscape.

The agreement explicitly states that any nonprofit entity providing services within Canada's public health-care system can freely obtain a license from Transgenomic to test for LQTS-associated genes. Consequently, any hospital or laboratory can now provide the test. To our knowledge, at least one Ontario hospital has done so thus far, representing a major advance over the pre-agreement situation.

Beyond this, the agreement establishes a blueprint for achieving similar access to any patented genetic test. Public entities seeking to provide testing involving any patented gene or method would first ask the relevant patentholders to sign an analogous agreement to provide a no-cost license in respect of those patents. If the patentholder refuses, then, under section 19 of the Patent Act-which is similar in this respect in most peer countries - the laboratory or hospital can request the Canadian Commissioner of Patents to compel the patentholder to sign. ${ }^{9,10} \mathrm{We}$ anticipate that it is unlikely that hospitals or laboratories will follow this procedure individually, given the expertise and resources required. Thus, for the agreement to be effective, the provinces, which fund the public health system, must take the lead, by providing guidance and support in obtaining mandatory licenses through the Commissioner of Patents.

Going forward, another critical concern for local providers and the broader clinical genomics community is ensuring rapid and accurate interpretation. ${ }^{21,30,31}$ Establishing highquality testing services involves two steps: (i) technical processing of samples, and (ii) interpretation of the clinical significance of identified variants. While the CHEO agreement allows laboratories to freely determine the sequence of patented genes, proper interpretation depends on consolidating information that is currently siloed across hundreds of databases located in different public and private clinical laboratories. ${ }^{32,33}$ Directors in this study underlined the need to share data and build partnerships with stakeholders across Canada and internationally to strengthen local capacity. Initiatives to promote scientific openness, and to support secure and ethically-compliant datasharing and interpretation are gathering steam in Canada and beyond. ${ }^{30,33,34}$ While some of the most comprehensive databases are held by commercial providers who exploited their patent rights to amass private collections, ${ }^{31}$ other commercial providers are strong advocates of collaborative, open approaches. ${ }^{17}$

Our analysis also highlights redundancy across institutions and provinces in assessing which tests should be locally established, and in implementation processes. This was exemplified by the lack of a coordinated response to gene patents within and across provinces. In Ontario, institutions were pitted against one another to win provincial test contracts, each seeking to independently "reinvent the wheel." At the very least, leadership by provincial authorities should promote, rather than obviate, shared solutions. A federally coordinated approach would offer economies of scale for the purchase of services, supplies, access to databases, analytical software, and so on.

\section{Limitations}

An important limitation of this study is the potential for bias inherent in the small sample size and the sampling methods 
used. We endeavored to mitigate this by seeking the participation of all relevant laboratories, and by triangulating interview data with publicly available information. We aimed for comprehensive and up-to-date understanding of relevant issues across institutions and provinces. However, in some jurisdictions it was challenging to garner research participants, and further, these systems are evolving (see Supplementary Results and Limitations for details). Our data reflect the context at the time of the interviews and recent follow-up inquiries.

\section{CONCLUSION}

With respect to the provision of clinical genetic testing, Canada is at an inflection point. Until now, law and practice have limited the ability of Canadian hospitals, laboratories and firms to innovate in this space, and they threaten future provision of next-generation sequencing testing. The CHEO agreement offers the potential to alter this landscape, but only if governments are proactive in their support of public healthcare-system stakeholders.

Beyond proper implementation of the $\mathrm{CHEO}$ agreement, continuing challenges include encouraging responsible sharing of genetic and phenotypic data; coordinating physical testing locations and interpretation expertise for particular disorders across provinces and the country; and coordinating assessments to guide adoption of novel and repatriated tests to maximize access, clinical impact, and cost-effectiveness. Other Canadian studies have called for inter-provincial coordination to optimize the equity and efficiency of genetic services. ${ }^{18,35}$ Our study underlines these calls for a national conversation. More broadly, the number of gene-related patents granted, at least in the United States, is increasing; ${ }^{4}$ thus, our study may be a harbinger of situations in other jurisdictions. Further study is needed to ascertain the effect of these patents on innovation and access, and to assess whether employment of the CHEO agreement should be considered. Finally, open discussion and collaboration will be an absolutely fundamental step towards maximizing the benefits of genomic medicine not only for Canadians, but for all global populations.

\section{SUPPLEMENTARY MATERIAL}

Supplementary material is linked to the online version of the paper at http://www.nature.com/gim

\section{ACKNOWLEDGMENTS}

We thank Clarissa Allen and Kendra Levasseur for their research assistance on this project.This study was funded under the PACEOMICS project, and supported by Genome Canada, Genome Québec, Genome Alberta, and the Canadian Institute for Health Research.

\section{DISCLOSURE}

E.R.G. provided policy advice to the Children's Hospital of Eastern Ontario in a lawsuit relating to the validity and scope of five patents related to LQTS. That case was settled before the present article was drafted. The authors declare no conflict of interest.

\section{REFERENCES}

1. Huys I, Matthijs G, Van Overwalle G. The fate and future of patents on human genes and genetic diagnostic methods. Nat Rev Genet 2012;13: 441-448.

2. Association for Molecular Pathology v. Myriad Genetics, Inc 2013 12-398:569 U.S. 133 S.Ct. 2107.

3. D'Arcy v. Myriad Genetics, Inc 2015 S28/2015.

4. Aboy M, Liddell K, Liddicoat J, et al. Myriad's impact on gene patents. Nat Biotechnol 2016;34:1119-1123.

5. Liddicoat J, Whitton T, Nicol D. Are the gene-patent storm clouds dissipating? A global snapshot. Nat Biotechnol 2015;33:347-352.

6. Braun V, Clarke V. Using thematic analysis in psychology. Qual Res Psychol 2006;3:77-101.

7. Ali-Khan SE, Gold ER Intellectual asset management in personalized medicine innovation: guide to a bibliography of literature on public policy implications 2016. http://paceomics.org/index.php/outputs/toolsand-resources/. Accessed August 25, 2016.

8. Global News. The genetic test you couldn't get in Canada, until now http://globalnews.ca/news/2567172/the-genetic-test-you-couldnt-get-incanada-until-now/ Accessed August 25, 2016.

9. CHEO. Challenging gene patent law: CHEO reaches ground-breaking agreement deal that changes landscape for genomic medicine. http:// www.cheo.on.ca/en/gene-patents. Accessed September 8, 2016.

10. Melnitzer J. Canadian patent settlement sets model for not-for-profit gene testing. http://business.financialpost.com/legal-post/canadian-patentsettlement-sets-model-for-not-for-profit-gene-testing.

11. Morse JM. The significance of saturation. Qualitative Health Research 1995;2:147-149.

12. Tong A, Sainsbury $P$, Craig J. Consolidated criteria for reporting qualitative research (COREQ): a 32-item checklist for interviews and focus groups. Int J Qual Health Care 2007;19:349-357.

13. QSR International. Discover the InVivo Suite. http://www.qsrinternational. com/nvivo-product. Accessed September 19, 2016.

14. Maxwell JA. Using numbers in qualitative research. 2010;16:475-482

15. Familion genetic testing for cardiovascular disorders. The FAMILION LQTS Test - The FIRST Comprehensive Genetic Test for LQTS http://mww. transgenomic.com/wp-content/uploads/602373.pdf. Accessed September 8, 2016.

16. Gene DX., Long QT Syndrome (LQTS). https://www.genedx.com/testcatalog/disorders/long-qt-syndrome-lqts/35212/. Accessed 8 September 2016.

17. Angrist M, Chandrasekharan S, Heaney C, et al. Impact of gene patents and licensing practices on access to genetic testing for long QT syndrome. Genet Med 2010;12:S111-S154.

18. Adair A, Hyde-Lay R, Einsiedel E, et al. Technology assessment and resource allocation for predictive genetic testing: a study of the perspectives of Canadian genetic health care providers. BMC Med Ethics 2009;10:6.

19. Allingham-Hawkins $D$, Casey $B$, Chitayat $D$, et al. A project to expand the capacity of genetic testing labs in Ontario, Canada. 2010 ACMG Annual Clinical Genetics Meeting, Albuquerque, NM.

20. Sullivan T, Gordon P, Minto S. Laboratory services expert panel final review. http://www.health.gov.on.ca/en/common/ministry/publications/ reports/lab_services/labservices.pdf.

21. Expert Panel on Quality Management. Project to establish a quality management program for repatriated genetic testing: report of the expert panel 2010. Meeting abstract from the 2010 annual American College of Medical Genetics (ACMG) meeting. Available at: http://acmg. omnibooksonline.com/2010/data/papers/309.pdf (accessed April 2017).

22. Hawkins $\mathrm{N}$. The impact of human gene patents on genetic testing in the United Kingdom. GenetMed 2011;13:320-324.

23. Gold ER, Carbone J. Myriad genetics: in the eye of the policy storm. GenetMed 2010;12:S39-S70.

24. Hopkins M, Hogarth S, Rodriguez V, et al. The role of patents in the development and clinical use of genetic tests. Final Report. Deliverable D3b. Case studies on the role of IP in the development and clinical use of genetic tests for Factor $V$ Leiden, TPMT and HPV in the USA and EU. https://www.sussex.ac.uk/webteam/gateway/file.php?name=sc30-wp3. pdf\&site=25 (accessed April 2017).

25. Gold RE, Cook-Deegan R, Bubela T. AMP v. Myriad: a surgical strike on Blockbuster business models. Sci Transl Med 2013;5:192ed9. 
26. Lilley M, Christian S, Blumenschein P, et al. A centralized approach to out-of-province genetic testing leads to cost savings: the Alberta experience. Clin Genet 2013;84:373-377.

27. Blumenschein CS, Lilley M. An assessment of Canadian systems for triaging referred out genetic testing. ClinGenet 2015;88:90-94.

28. Sherkow JS, Scott C. Myriad stands alone. Nat Biotechnol 2014;32:620.

29. Richer J, Nelson TN, Evans J, et al. CCMG statement on gene patents. ClinGenet 2012;82:405-407.

30. Lerner-Ellis J, Wang M, White $S$, et al. Canadian Open Genetics Repository (COGR): a unified clinical genomics database as a community resource for standardising and sharing genetic interpretations. J Med Genet 2015;52:438-445.

31. Cook-Deegan R, Conley JM, Evans JP, et al. The next controversy in genetic testing: clinical data as trade secrets? Eur J Hum Genet 2013;21:585-588.

32. Kapa S, Tester DJ, Salisbury BA, et al. Genetic testing for long-QT syndrome: distinguishing pathogenic mutations from benign variants. Circulation 2009;120:1752-1760.

33. Global Alliance for Genomics and Health. GENOMICS. A federated ecosystem for sharing genomic, clinical data 2016;352:1278-1280.

34. Owens B. DATA SHARING. Montreal institute going 'open' to accelerate science. Science 2016;351:329.
35. Christian S, Blumenschein P, Lilley M. An assessment of Canadian systems for triaging referred out genetic testing. Clin Genet 2015;88: 90-94.

(1) () $\odot$ This work is licensed under a Creative Commons Attribution-NonCommercial-NoDerivs $\quad 4.0$

International License. The images or other third party material in this article are included in the article's Creative Commons license, unless indicated otherwise in the credit line; if the material is not included under the Creative Commons license, users will need to obtain permission from the license holder to reproduce the material. To view a copy of this license, visit http://creativecommons.org/licenses/ by-nc-nd/4.0/

(C) The Author(s) 2017 